\title{
Canadian Forestry Accreditation Board Annual Report - 2011
}

The Canadian Forestry Accreditation Board (CFAB) is responsible for the assessment of Canadian university forestry degree programs for the purpose of meeting academic requirements for professional certification (registration/licensure). Its role is to implement a national accreditation review process mandated under a detailed Policy Statement agreed to by its member agencies, the eight professional forester/forest engineer associations of Canada, and the Canadian Institute of Forestry. Board members are appointed by the member agencies.

The Board was established in 1989 and has been conducting site visitations since 1990. Assessment of academic program is undertaken in accordance with comprehensive academic standards but also includes consideration of facilities and services offered; faculty experience, qualifications and tenure; and the ability of the program to imbue professional qualifications and qualities in students. The regular accreditation cycle for a program is six years, although circumstances may dictate a shorter period for a given program or an interim review to confirm that a program continues to meet accreditation requirements. At present, eleven baccalaureate forestry programs in Canada enjoy accredited status. The Board does not accredit faculties or institutions, nor does it review programs outside Canada.

The Board's fourth round of reviews continued in 2011 with two site visits. Accreditation reviews of the Forest Ecosystem Management and Forest Engineering (R.P.F. option) Programs, Faculty of Forestry and Environmental Management, University of New Brunswick were undertaken in March. The review team comprised Faye Johnson, R.P.F. (Lead), Victor Brunette, ing.f., Vidar Nordin, R.P.F. and Blair Pardy, R.P.F. The second site visit, to the Faculty of Agricultural, Life and Environmental Sciences, University of Alberta for review of the school's Forestry and Forest Business Management Programs, was completed in April. That review team comprised
Peter Marshall, R.P.F. (Lead), Keith Branter, R.P.F., Nancy Luckai, R.P.F. and Evelynne Wrangler, R.P.F.

The Board met once during the year, on September 7 in Quebec City. Following consideration of the review team reports and related documentation, the Board granted two-year accreditations to the Forest Ecosystem Management Program (FEM) and Forest Engineering (R.P.F. option) Program (FE) at the University of New Brunswick. The accreditation periods began with the 2011/12 academic year and extend to June 30, 2013.The new accreditation of the former program (FEM) is extendable to a full, six-year period upon the Faculty providing evidence satisfactory to the Board that actions specified in the Accreditation Decision have been taken to address standards-related program gaps. The previous accreditation of the latter program (FE) has been extended for two years. That decision is predicated on the understanding that the Program's R.P.F. option will be terminated in 2013 and that there will be no new enrolments in the option over the period of the extended accreditation.

At the same meeting, the Board determined as well that the Forestry and Forest Business Management Programs at the University of Alberta would be accredited for the maximum period of six years. Accreditations of those programs began with the 2011/2012 academic year and continue to June 30, 2017. Status and update reports have been requested of the school to determine progress on a number of action items referred to in the respective Accreditation Decisions.

Accreditation determinations are subject to all relevant provisions of the Policy Statement which declares that, among others, "the term of the accreditation is subject to review for cause at

\section{Status of CFAB Program Accreditations at Canadian Schools of Forestry - December 2011}

\begin{tabular}{|c|c|c|}
\hline April 2005 & $\begin{array}{l}\text { University of British Columbia, Faculty of Forestry, } \\
\text { Forest Resources Management Program and Forest } \\
\text { Operations Program }\end{array}$ & $\begin{array}{l}\text { Accredited for six years } \\
\text { to June } 30,2011 \text { (extended } \\
\text { to June } 30,2012 \text { ) }\end{array}$ \\
\hline August 2006 & $\begin{array}{l}\text { Lakehead University, Faculty of Natural Resources } \\
\text { Management, Forestry Program (H.B.Sc.F.) }\end{array}$ & $\begin{array}{l}\text { Accredited for six years } \\
\text { to June } 30,2012\end{array}$ \\
\hline Sept. 2009 & $\begin{array}{l}\text { Laval University, Faculty of Forestry, Geography and } \\
\text { Geomatics, Forest Management and Environment } \\
\text { Program and Forest Operations Program }\end{array}$ & $\begin{array}{l}\text { Accredited for six years } \\
\text { to June } 30,2015\end{array}$ \\
\hline Sept. 2009 & $\begin{array}{l}\text { University of Northern British Columbia, College of } \\
\text { Science and Management, Ecosystem Science and } \\
\text { Management Program, Forest Ecology and } \\
\text { Management Major }\end{array}$ & $\begin{array}{l}\text { Accredited for six years } \\
\text { to June } 30,2015\end{array}$ \\
\hline Sept. 2010 & $\begin{array}{l}\text { University of Moncton, Faculty of Forestry, } \\
\text { Forestry Sciences Program }\end{array}$ & $\begin{array}{l}\text { Accredited for three } \\
\text { years to June 30, } 2013\end{array}$ \\
\hline Sept. 2011 & $\begin{array}{l}\text { University of New Brunswick, Faculty of Forestry } \\
\text { and Environmental Management, Forest Ecosystem } \\
\text { Management Program }\end{array}$ & $\begin{array}{l}\text { Accredited for two } \\
\text { years to June 30, } 2013\end{array}$ \\
\hline Sept. 2011 & $\begin{array}{l}\text { University of New Brunswick, Faculty of Forestry and } \\
\text { Environmental Management, Forest Engineering } \\
\text { Program (R.P.F. option) }\end{array}$ & $\begin{array}{l}\text { Accreditation extended } \\
\text { for two years to June } 30 \text {, } \\
2013\end{array}$ \\
\hline Sept. 2011 & $\begin{array}{l}\text { University of Alberta, Faculty of Agricultural, Life and } \\
\text { Environmental Sciences, Alberta School of Forest Science } \\
\text { and Management, Forestry Program and Forest Business } \\
\text { Management Program }\end{array}$ & $\begin{array}{l}\text { Accredited for six years } \\
\text { to June } 30,2017\end{array}$ \\
\hline
\end{tabular}

P.L. Marshall, R.P.F., Chairman, L.F. Riley, R.P.F., Executive Director 
any time." Accreditations under the current decisions apply only to the curricula referred to above and in place at the time of the accreditation reviews.

With the agreement of the schools, regularly scheduled reviews of the Forest Resources Management and Forest Operations Programs at the University of British Columbia (Faculty of Forestry) and of the H.B.Sc.F. Forestry Program at Lakehead University (Faculty of Natural Resources Management) will be undertaken in April 2012. The current accreditations of the three programs expire at the end of June 2012. These visits will conclude the fourth round of reviews, and the first round of reviews employing the competencybased academic standards approved for Board use by the Canadian Federation of Professional Foresters Associations (CFPFA) in 2008.

No further regularly scheduled reviews will be conducted until late 2014 or early 2015 although interim review actions are anticipated at both the University of Moncton and the University of New Brunswick.

No changes in Board membership occurred during the year. Board members and alternates at the end of 2011 were Peter Marshall, R.P.F. (Chairman) and Randy Trerise, R.P.F. (alt.), Association of BC Forest Professionals; Janet
Schilf, R.P.F. and Charles Backman, R.P.F. (alt.), College of Alberta Professional Foresters; John Daisley, R.P.F. and John Doucette, R.P.F. (alt.), Association of Saskatchewan Forestry Professionals; Faye Johnson, R.P.F. and David Winston, R.P.F. (alt.), Ontario Professional Foresters Association; Germain Paré, ing.f. and Jean-Louis Brown, ing.f. (alt.), Ordre des ingénieurs forestiers du Québec; Peggy McDougall, R.P.F. and Rod O'Connell, R.P.F. (alt.), Association of Registered Professional Foresters of New Brunswick; Ian Millar, R.P.F. and Roger Aggas, R.P.F. (alt.), Registered Professional Foresters Association of Nova Scotia; Bill Buggie, R.P.F. and Glen Knee, R.P.F. (alt.), Registered Professional Foresters of NewfoundlandLabrador; and Bruce Dancik, R.P.F., Canadian Institute of Forestry. Most of those serving at the 2011 year end are expected to continue their participation in 2012.

As a member agency, the Board remained fully active in the meetings and activities of the CFPFA and a standing sub-committee, the Central Assessment Authority (CAA). The former serves as an umbrella organization for discussion of matters of national relevance to Canadian forester and forest engineer regulatory bodies and functions under a member-agency agreed set of by-laws. The latter is a recently formed sub-element to oversee and administer the CFPFA's newly implemented national program for the assessment of the credentials of foreigntrained individuals and graduates from non-accredited Canadian forestry programs who seek to enter professional forestry practice in Canada. Information for candidates seeking assessment procedure information is available on a CFAB sub-site at www.cfab.ca/cfpfafcafp. The CFPFA is in the process of developing a standalone Web site for this and other CFPFA-related activity.

The Board is an active member of the Association of Accrediting Agencies of Canada (AAAC). The AAAC convenes two meetings annually at which the 34 member agencies, representing the majority of baccalaureate and higher program accrediting bodies in Canada, are able to consider items of mutual interest and to share accreditation experiences and procedures.

The CFAB Annual Report for 2010, including the then current record of accredited programs, was published in the May/June 2011 issue of The Forestry Chronicle.

Lorne F. Riley, R.P.F. Executive Director January 9, 2012

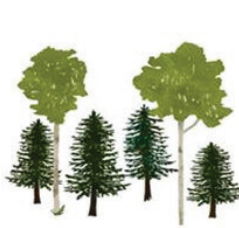 \\ Boreal Mixedwoods 2012 \\ Ecology and Management for Multiple Values \\ June 17-20, 2012 \\ Delta Edmonton South, Edmonton, Alberta \\ http.//Www.ualberta.ca/ pcomeau/mixedwoods2012/borealmixedwoods2012.htm}

\section{Hosted by the Canadian Wood Fibre Centre, University of Alberta and the Western Boreal Growth and Yield Association}

The Boreal Mixedwoods 2012 conference will provide a forum for presentation and discussion of current knowledge relating to the ecology and management of mixedwood stands and landscapes to achieve ecological, social and economic objectives.

A 2-day technical field tour June 21-22 will follow the formal conference.

The tour will profile boreal mixedwood management systems contributing to a sustainable and competitive forest industry in Alberta, following the conference theme.

Deadline for submission for articles is March 10, 2012 for Volunteer Papers, Discussion Sessions and Poster Sessions

Book by May 14, 2012 to receive the early bird registration prices

(\$325 regular, $\$ 200$ for students/retired).

Call the Delta Edmonton South at 1-800-661-1122 by May 18 to secure a room at the reduced conference rate.

Please check the conference Web site for more information on how to register: http://www.ualberta.ca/ pcomeau/mixedwoods2012/borealmixewoods2012.html 
e Bureau canadien d'agrément en - foresterie (BCAF) est responsable de lévaluation des programmes universitaires de foresterie au Canada afin de s'assurer qu'ils rencontrent les exigences académiques de la certification professionnelle (admission à un ordre professionnel). Son rôle est de mettre en œuvre un processus national d'agrément, en vertu du mandat défini dans l'Énoncé de politique approuvé par ses organismes membres, soit les huit associations canadiennes de professionnels forestiers (ingénieurs forestiers) et l'Institut forestier du Canada. Le Bureau est formé des représentants désignés par les organismes membres.

Le Bureau a été créé en 1989 et a entrepris l'évaluation des programmes en 1990. L'évaluation d'un programme est entreprise selon des normes de scolarité reconnues mais comprend également l'examen détaillé des installations et des services offerts, de l'expérience, des qualifications et des postes détenus par les professeurs, ainsi que de la capacité du programme d'inculquer aux étudiants les qualités et les qualifications professionnelles requises pour la pratique de la profession. Le cycle habituel d'agrément d'un programme est de six ans, mais les circonstances peuvent dicter une période plus courte pour un programme donné ou une révision intérimaire, afin de s'assurer qu'il satisfait toujours aux critères d'agrément. Actuellement, onze programmes de baccalauréat en foresterie sont agréés au Canada. Le Bureau nagrée pas les facultés, ni les institutions ainsi que les programmes d'étude dispensés hors du Canada.

Le quatrième cycle de révision entrepris par le Bureau sest poursuivi en 2011 avec deux visites dévaluation. La révision de l'agrément des Programmes d'Aménagement de l'écosystème forestier et de Génie forestier (option R.P.F.) de la Faculté de Foresterie et de Gestion de l'Environnement de l'Université du Nouveau-Brunswick a été effectuée en mars. L'équipe de révision était formée de Faye Johnson, R.P.F (Directeur), de Victor Brunette, ing.f., de Vidar Nordin, R.P.F. et de Blair Pardy, R.P.F. La deuxième visite d'évaluation, effectuée à la Faculté d'Agriculture, des Sciences de la Vie et de l'Environnement de l'Université de l'Alberta afin de réviser les
Programmes de Foresterie et de Gestion des Affaires en Foresterie, a été complétée en avril. Cette équipe de révision était formée de Peter Marshall, R.P.F. (Directeur), de Keith Branter, R.P.F., de Nancy Luckai, R.P.F. et d'Evelynne Wrangler, R.P.F.

Le Bureau s'est réuni à une occasion au cours de l'année, le 7 septembre à Québec. À la suite de l'étude du rapport des équipes de révision et de la documentation qui s'y rattachait, le Bureau a accordé un agrément d'une durée de deux ans au Programme d'Aménagement de l'écosystème forestier (AEF) et au Programme de Génie forestier (option R.P.F) (GF) de l'Université du Nouveau-Brunswick. La nouvelle période d'agrément débute avec l'année scolaire 2011-2012 et se poursuit jusqu'au 30 juin 2013. Le nouvel agrément du premier programme (AEF) pourra couvrir la durée normale de six ans à condition que la Faculté apporte au Bureau des preuves concrètes que les mesures spécifiées dans la Décision d'agrément ont été appliquées pour résoudre les lacunes du programme relativement aux normes. L'agrément précédent du second programme (GF) a été prolongé de deux ans. Cette décision découle du fait que l'option R.P.F. du Programme arrivera à échéance en 2013 et qu'il n'y aura aucune nouvelle inscription permise pour cette option au cours de la prolongation.

Au cours de cette réunion, le Bureau a déterminé également que les Programmes de Foresterie et de Gestion des Affaires en Foresterie de l'Université de l'Alberta seraient agréés pour une durée maximale de six ans. Lagrément de ces programmes a débuté avec l'année scolaire 2011-2012 et se poursuivra

\section{Programme des facultés canadiennes de foresterie agréés par le BCAF - Décembre 2011}

\begin{tabular}{|c|c|c|}
\hline Avril 2005 & $\begin{array}{l}\text { Université de la Colombie-Britannique, Faculté de } \\
\text { Foresterie, Programme d'Aménagement des ressources } \\
\text { forestières et Programme d'Exploitation forestière }\end{array}$ & $\begin{array}{l}\text { Agréés pour une période de six } \\
\text { ans se terminant le } 30 \text { juin } 2011 \\
\text { (agréments prolongés jusquau } \\
30 \text { juin 2012) }\end{array}$ \\
\hline Août 2006 & $\begin{array}{l}\text { Université Lakehead, Faculté d’Aménagement des } \\
\text { Ressources naturelles, Programme de Foresterie } \\
\text { (H.B.Sc.F.) }\end{array}$ & $\begin{array}{l}\text { Agréé pour une période de six } \\
\text { ans se terminant le } 30 \text { juin } 2012\end{array}$ \\
\hline Sept. 2009 & $\begin{array}{l}\text { Université Laval, Faculté de Foresterie, de Géographie } \\
\text { et de Géomatique, Programme d'Aménagement et } \\
\text { Environnement forestiers et Programme des } \\
\text { Opérations forestières }\end{array}$ & $\begin{array}{l}\text { Agréé pour une période de six } \\
\text { ans se terminant le } 30 \text { juin } 2015\end{array}$ \\
\hline Sept. 2009 & $\begin{array}{l}\text { Université du Nord de la Colombie-Britannique, } \\
\text { Collège des Sciences et de l’Aménagement, } \\
\text { Programme des Sciences des écosystèmes et de } \\
\text { l'Aménagement (majeure en écologie et aménagement } \\
\text { forestier) }\end{array}$ & $\begin{array}{l}\text { Agréé pour une période de six } \\
\text { ans se terminant le } 30 \text { juin } 2015\end{array}$ \\
\hline Sept. 2010 & $\begin{array}{l}\text { Université de Moncton, Faculté de Foresterie, } \\
\text { Programme des Sciences forestières }\end{array}$ & $\begin{array}{l}\text { Agréé pour une période de } \\
\text { trois ans se terminant le } \\
30 \text { juin } 2013\end{array}$ \\
\hline Sept. 2011 & $\begin{array}{l}\text { Université du Nouveau-Brunswick, Faculté de } \\
\text { Foresterie et de Gestion de l'Environnement, Pro- } \\
\text { gramme d'Aménagement des écosystèmes forestiers }\end{array}$ & $\begin{array}{l}\text { Agréé pour une période de } \\
\text { deux ans se terminant le } \\
30 \text { juin } 2013\end{array}$ \\
\hline Sept. 2011 & $\begin{array}{l}\text { Université du Nouveau-Brunswick, Faculté de } \\
\text { Foresterie et de Gestion de l'Environnement, } \\
\text { Programme de Génie forestier (option R.P.F.) }\end{array}$ & $\begin{array}{l}\text { Agréé pour une période de } \\
\text { deux ans se terminant le } \\
30 \text { juin } 2013\end{array}$ \\
\hline Sept. 2011 & $\begin{array}{l}\text { Université de l'Alberta, Faculté des Sciences de } \\
\text { l'Agriculture, de la Vie et de l'Environnement, École } \\
\text { des Sciences forestières et de l'Aménagement de } \\
\text { l'Alberta, Programme de Foresterie et Programme } \\
\text { de Gestion des Affaires en Foresterie }\end{array}$ & $\begin{array}{l}\text { Agréés pour une période de } \\
\text { six ans se terminant le } \\
30 \text { juin } 2017 .\end{array}$ \\
\hline
\end{tabular}

P.L. Marshall, R.P.F., Président, L.F. Riley, R.P.F., Directeur général 
jusqu'au 30 juin 2017. Des rapports permettant de faire le point ou la mise à jour des démarches entreprises ont été exigés par le Bureau afin de déterminer les progrès réalisés par l'école sur un certain nombre de points identifiés dans les Décisions d'agrément.

Ces décisions sont assujetties aux dispositions pertinentes de l'Énoncé de politique qui indique, entre autres, que " la durée de l'agrément peut être remise en question en tout temps pour raison valable ». Les agréments accordés par les présentes décisions s'appliquent seulement au cheminement scolaire du programme mentionné ci-dessus et en place au moment de la révision de l'agrément.

Avec l'accord des établissements, les révisions prévues de l'agrément des Programmes d'Aménagement des Ressources forestières et d'Opérations forestières de l'Université de la Colombie-Britannique (Faculté de Foresterie) et du Programme de Foresterie (H.B.Sc.F.) de l'Université Lakehead (Faculté d'Aménagement des Ressources naturelles) seront effectuées en avril 2012. Lagrément actuel de ces trois programmes se termine à la fin de juin 2012.Ces visites seront les dernières du quatrième cycle de révision et du premier cycle de révision selon les normes académiques de compétence approuvées pour être utilisées par le Bureau par la Fédération canadienne des associations de professionnels forestiers (FCAFP) en 2008.

Aucune autre révision régulière ne sera entreprise avant la fin 2014 ou le début de 2015, même si des révisions intérimaires sont envisagées à l'Univer- sité de Moncton et à l'Université du Nouveau-Brunswick.

Il n'y a eu aucun changement parmi les membres du Bureau au cours de l'année. Les membres du Bureau ainsi que les substituts à la fin de 2011 étaient Peter Marshall, R.P.F. (Président) et Randy Trerise, R.P.F. (subst.), Association of British Columbia Forest Professionals; Janet Schilf, R.P.F. et Charles Backman, R.P.F. (subst.), College of Alberta Professional Foresters; John Daisley, R.P.F. et John Doucette, R.P.F. (subst.), Association of Saskatchewan Forestry Professionals; Faye Johnson, R.P.F. et David Winston, R.P.F. (subst.), Ontario Professional Foresters Association; Germain Paré, ing.f. et Jean-Louis Brown, ing.f. (subst.), Ordre des ingénieurs forestiers du Québec; Peggy McDougall, R.P.F. et Rod O'Connell, R.P.F. (subst.), Association des Forestiers agréés du Nouveau-Brunswick; Ian Millar, R.P.F. et Roger Aggas, R.P.F. (subst.), Registered Professional Foresters Association of Nova Scotia; Bill Buggie, R.P.F. et Glen Knee, R.P.F. (subst.), Registered Professional Foresters of Newfoundland-Labrador et Bruce Dancik, R.P.F., Institut forestier du Canada. La plupart des membres désignés à la fin de 2011 devraient poursuivre leur participation au cours de 2012.

En tant que membre, le Bureau participe activement aux réunions et aux activités de la FCAFP, en particulier au niveau d'un sous-comité permanent, l'Instance centrale d'évaluation (ICE). La FCAFP est un regroupement permettant de discuter des sujets pertinents pour les organisations chargées de la réglementation des forestiers et des ingénieurs forestiers au Canada et qui fonctionne selon un ensemble de règlements internes approuvés par les organismes membres. L'ICE est un sous-élément de formation récente destiné à superviser et à gérer le programme national récemment implanté par la FCAFP pour évaluer les références des personnes formées à l'étranger et des diplômés des programmes canadiens de foresterie non agréés qui cherchent à accéder à la pratique professionnelle de la foresterie au Canada. Des informations destinées aux personnes cherchant plus de renseignements sur la procédure d'évaluation sont disponibles sous un onglet du site internet du BCAF à : www.cfab.ca/cfpfa-fcafp. La FCAFP procède à l'élaboration de son propre site internet à cette fin et pour les autres activités reliées à la FCAFP.

Le Bureau est un membre actif de l'Association des agences d'agrément du Canada (AAAC). L’Association se réunit deux fois par année et les 34 organismes membres, représentant la majorité des organismes d'agrément des programmes de baccalauréat et détudes supérieures du Canada, ont loccasion lors de ces réunions détudier les éléments d'intérêt commun en matière d'agrément et de partager leur expertise et des procédures d'agrément.

Le rapport annuel du BCAF pour l'année 2010, qui comprenait la liste des programmes agréés au moment de sa parution a été publié dans le numéro de mai/juin 2011 de la revue The Forestry Chronicle.

Lorne F. Riley, R.P.F

Directeur général 9 janvier 2012

\section{$10^{\text {th }}$ Canadian Urban Forest Conference}

\begin{abstract}
ree Canada and the City of London, in partnership with the Society of Municipal Arborists and the Ontario Urban Forest Council, invites you to the $10^{\text {th }}$ Canadian Urban Forest Conference in London, Ontario October $2^{\text {nd }}-$ $4^{\text {th }}$. London, The Forest City, has a long history of progressive and innovative forest management. With over $80 \%$ of Canadians living in urban areas, London will provide a focus for Canadian urban forest practices and allow a dialogue with professional and community
\end{abstract}

groups on urban forest strategies, policies, technologies and management practices.

Online registration for Back to the Forest Conference is available at www.cufc10.ca.Visit the Web site often as Program and Conference details will be updated frequently. The bilingual conference will include:

- A strategic urban forest workshop and quality local, national and international presenters

- Field tours of London's urban forest and Canada's unique Carolinian Forest

- A banquet and gala event marking Tree Canada's $20^{\text {th }}$ anniversary

- Networking and dialoguing opportunities with Canadian urban forest leaders

For further information contact Louise Fagan, CUFC10 Project Manager, louise.fagan03@gmail.com or Melissa Nisbett, Communications Officer, Tree Canada, mnisbett@ treecanada.ca. 
D 011 , the International Year of Forests 4 was a busy one for the Ontario Forestry Association. Between staff changes and an office move OFA managed to expand programs and continue to connect with people across the province.

Ontario's provincial Envirothon champions, West Hill Secondary School from Owen Sound took second place at the Canon Envirothon July $24^{\text {th }}-29^{\text {th }}$ in Sackville New Brunswick (outdone only by Manitoba's provincial team). With over 50 teams competing from across Canada and the US this was a significant achievement for the team and for the provincial program. Tree Bee, the annual tree ID competition for primary students reaches its milestone $60^{\text {th }}$ year in 2012.

Through its Focus on Forest program OFA continues to partner with Majesta and Tree Canada and are engaged in the $2^{\text {nd }}$ annual cross-Canada Trees of Knowledge competition, providing a $\$ 20000$ outdoor classroom to the winning school. St. Paul's Elementary, Beaconsfield QC was the 2011 winner and
2012 submissions are currently under review. OFA's Forestry Connects program in 2011 brought 15 Southern Ontario students to Dryden for a week to participate in Conservation Camp and get a peek at Ontario's boreal forest. The 2012 program will run from May $27^{\text {th }}$-June $1^{\text {st }}$ and applications are open for participants.

In the fall of 2011 MNR made the final decision to assume full responsibility for the administration and delivery of the Managed Forest Tax Incentive Program in January 2012. The OFA will provide assistance and training during the transition period from January 1st to August 31st 2012. It will continue to play a strong role in private land forestry and provide information and support to members and landowners. New initiatives for this year are being considered, such as forest certification and payment for ecological services.

The OFA held an International Forest Film Fest in November in partnership with the Faculty of Forestry, University of Toronto to celebrate the close of the International Year of Forests. The event drew over 150 attendees to watch a collection of new and old videos, provided in part by the Jackson Hole Wildlife Film Festival.

More recently the OFA held its $63^{\text {rd }}$ Annual Conference and AGM on February 10, 2012. The event "Prescription for Nature: Healthy Forests for Healthy People" drew some 300 landowners, educators, students and natural resource professionals to talk about forest health, human health and their connection.

The OFA continues to have strong online presence through its various social media networks and is active on Twitter, Facebook and YouTube. In 2011, OFA launched its first e-newsletter which is available on request. It contains news articles focused on themes relevant to members and supporters including forest education, stewardship, and green news.

See: www.oforest.ca for further information or telephone: 1-800-387-0790.

\section{Expertise Meets Quality - Building a Better Urban Forest through Public-Private Partnerships}

o you have an idea for an urban forestry project but don't know where to start? No money? No partnerships? Back in 2010 London, Ontario "The Forest City" and host of the $10^{\text {th }}$ Canadian Urban Forest Conference (www.cufc10.ca), began a major project to plant trees and shrubs and develop commemorative features along the Veterans Memorial Parkway (VMP). Securing funding was an issue until organizers were approached to create a public-private partnership to complete the ambitious plan. The Veterans Memorial Parkway Community Program was born out of this partnership which aims to plant 8000 caliper trees and construct 15 commemorative features along the $10 \mathrm{~km}$ VMP over the next five years.

"We wanted to honour our veterans, plant lots of trees, beautify a major gateway into London and involve the greater community", said Barry Sandler, Executive Director, Veterans Memorial Parkway Community Program. "The progressive thinking of Mayor Joe Fontana-who embraced the proposal of a community partnership-and the on-going support of the City's professional staff from several program divisions has enabled us to participate in our city's development." To fund a largescale project with the city alone would have "cost millions that the city did not have," cited Sandler.

The business community rallied around the idea and 3M, Starlin North America and Trojan Technologies became major sponsors. A key strategy to bring the plan to fruition and keep costs in line was to access expertise by recruiting professional volunteersmembers of the horticultural communities and the City's Forestry and Parks Planning and Development staff.
A partnership with the local chapter of Landscape Ontario has enabled organizers to plant larger $50-60 \mathrm{~mm}$ stock and choose salt- and pollutiontolerant species that will increase survivability rates along the Parkway. By committing to one day of volunteering, Landscape Ontario crews had trees delivered to the site and dug holes for large root balls, leaving the infill, mulching and staking for community members to finish.

Trees will be planted in blocks of 100 to create "living guards of honour" that represent a traditional military formation. Residents can purchase a tree and visit a parkette with a memorial wall where Londoners can learn in what block their tree was planted. A community advisory committee was created to act as a forum so members of the public can provide suggestions and understand the reasons behind planting 
decisions. Community support has included reaching out to the local Scouts Canada chapter, Argyle Community Association, and countless veteran groups to spread the word and divide duties. Keeping the community involved is crucial for the support of the project.

Last fall, 1000 trees and shrubs were planted by the City and 200 caliper trees were planted by hundreds of volunteers in the first of the VMP Community Program projects.

Tips for Developing Your Own Private-Public Project

- Build Support: Reach out to your municipality about your project. Do your research and offer possible planting sites, how the city/town may get involved and how businesses and the greater community might support your plans.

- Connect with experts: Your community forestry committee and horticultural businesses have the expertise you need. Discuss your ideas with them and opportunities they can get involved long term. Be conscious of their time.

- Practice Transparency: Keep your community informed by creating a public committee. Ensure any questions by the public are answered.
Their support, and understanding of the project, is key to your success.

Want to learn more? Attend the Canadian Urban Forest Conference in London Oct. 2-4, 2012. www.cufc10.ca.

Melissa Nisbett, Tree Canada

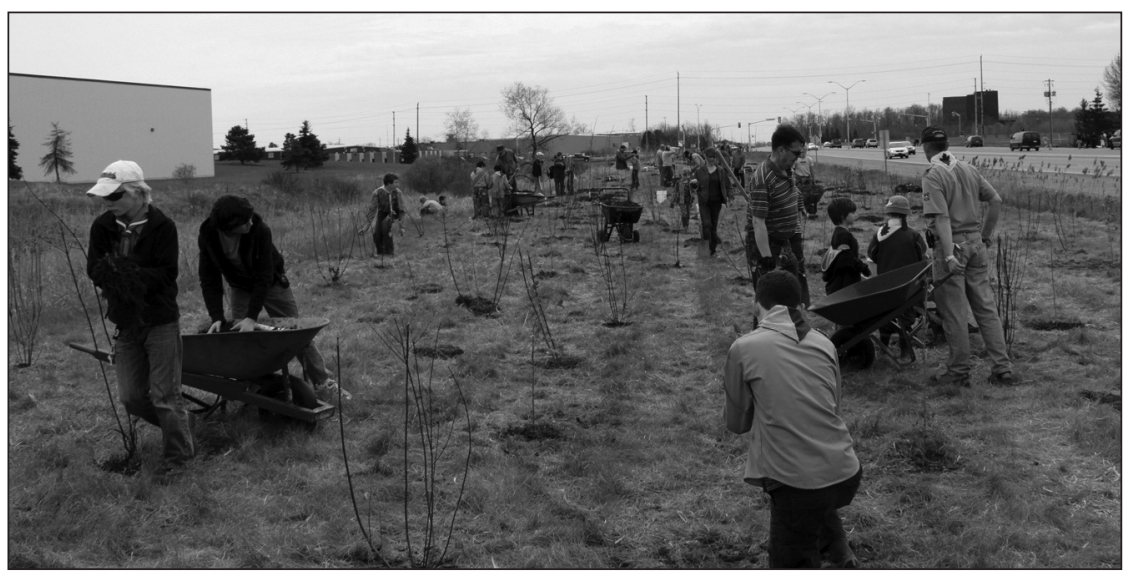

Beavers, Cubs and Scouts, with their leaders and parents, tree planting along the Veterans Memorial Parkway leading into London.

\section{Forest Heroes Receive Special Recognition}

I eople who have made special contributions towards protecting forests and forest communities received the Forest Heroes Award at a special ceremony hosted by the United Nations Forum on Forests (UNFF) Secretariat February $9^{\text {th }}$ to mark the conclusion of the International Year of Forests.

In addition to the presentation of Forest Heroes Awards, the ceremony featured the winners of the 2011 Universal Postal Union letter-writing contest, which drew entries from more than two million children and youth worldwide, and the announcement of the winners of the 2011 children's art contest "Celebrate the Forests". There were also film clips from the first-ever awardwinning International Forest Film Festival, as well as the launch of the commemorative book Forests for People with 75 articles from 35 countries.

Jan McAlpine, Director of the United Nations Forum on Forests Secretariat and a member of the jury panel for the Forest Heroes Awards, said the well-being of forests was a concern for everyone. "Each of us, all seven billion people on Earth, has our physical, economic and spiritual health tied to forests. We launched the UNFF Forest Heroes Awards for the International Year of Forests 2011 to identify and honour individuals around the world who are dedicating their lives to nurturing forests in quiet and heroic ways. The program aimed to spotlight everyday people working to make positive changes for forests."

The UNFF Secretariat received 90 nominations from 41 countries and selected 15 finalists. Fred Pinto of North Bay, Ontario was nominated by the Canadian Institute of Forestry/Institut forestier du Canada (CIF/IFC), and was one of the finalists and one of three considered for the prestigious North American region. Mr. Pinto has been a voluntary member of the CIF/IFC for over 30 years and served on the National Board of Directors. In 2006 he began a four-year term on the Institute's National Executive. In addition, he is considered the visionary who led the initiative that created the charity "Forests without Borders", dedicated to helping communities throughout the world to restore forest ecosystems and achieve sustainability. Mr. Pinto has also devoted a great deal of his time to teaching young forest professionals, helping them to develop a broad and balanced understanding of forestry.

After a lengthy and difficult deliberation, the jury finally decided on the following regional winners: Africa's Paul Nzegha Mzeka (Cameroon), Asia's Shigeatsu Hatakeyama (Japan), Europe's Anatoly Lebedev (Russian Federation), Latin America's Paulo Adario (Brazil) and North America's Rhiannon Tomtishen and Madison Vorva (United

Fred Pinto of North Bay, Ontario was nominated by the Canadian Institute of Forestry/Institut forestier du Canada (CIF/IFC), and was one of the finalists and one of three considered for the prestigious North American region.

States). The jury added a special award in recognition of the deceased couple José Claudio Ribeiro and Maria do Espírito Santo, two activists tragically murdered in Brazil while trying to protect their natural forests. Each hero embodied innovative approaches and 
grass-roots initiatives that make a direct impact on the forests to which they have dedicated themselves.

Through education, reforestation, and sustainable bee farming, Paul Mzeka and his team have helped 30 communities in Cameroon to protect their watersheds and conserve community forests. He still works tirelessly at the age of 77. Shigeatsu Hatakeyama, an oyster fisherman, understands the role of forests in maintaining clean water for his oyster beds and has become an iconic advocate of sustainable forests and farming practices in Miyagi, an area of Japan recently devastated by the March 2011 earthquake and tsunami.
Anatoly Lebedev, working through the legislative system, as well as through outreach and education, has successfully campaigned against illegal logging and destructive land practices in the Russian Federation that threatened indigenous communities and Siberian tigers. Paulo Adario has dedicated himself to the protection of rainforests and forest-dependent communities in the Brazilian Amazon despite death threats and warring interest groups. The North American regional winners were Ms. Rhiannon Tomtishen and Ms. Madison Vorva of the United States. As 11-yearold girl scouts, they worked to raise awareness about palm oil, which is linked to the destruction of rainforests and an ingredient used in girl-scout cookies. Now 16, these inspiring girls are working to educate consumers and persuade multinational companies, such as Kellogg's and Cargill, to change their supply-chain practices to help reduce deforestation.

While these Forest Heroes come from varied backgrounds, they share a common courage, passion and perseverance that serve as inspiration to anyone wishing to make a difference for forests. For more information, see: www.un.org/forests.

Source un.org/news release

\section{Hybrid Ash May Stand up to EAB}

W hen emerald ash borers (EAB) were discovered near Detroit in 2002, government officials spent millions of dollars in an attempt to destroy the insects before they destroyed millions of trees. Unfortunately, the program was unsuccessful and a decade later, some scientists say the key to saving North American ash trees may lie locked within the genetic code of Asian ash species and a few individual Michigan ash trees that managed to survive the initial invasion.

Preliminary results from a multiyear effort to create a borer-resistant ash were promising enough to persuade the U.S. Department of Agriculture (USDA) to award a $\$ 1.4$ million grant to a team of researchers led by the Ohio Agricultural Research and Development Center in Wooster, Ohio. The money will help support efforts to identify the genes, proteins and enzymes that Asian ash species use to resist borer attacks. It also will fund work to crossbreed those resistance traits into North American ash species.

The project began in 2003 and has received more than $\$ 2.3$ million in federal and state grants. Besides money, this type of work requires patience. It will take years to successfully breed and test a resistant plant, according to Dan Herms, an Ohio State University entomologist. "If we are there by 2020, that would be really, really good progress."

The stakes are high. North American ash species are nearly $100 \%$ susceptible to the emerald ash borer. Borer larvae, which likely came to the United States in wooden crates shipped from China, kill ash by creating tunnels beneath the bark in the soft wood that supplies the trees with water and nutrients. EAB has wiped out tens of millions of ash trees in Michigan, Ohio, Illinois, Indiana, Kentucky, Minnesota, Missouri, New York, Ontario, Pennsylvania, Tennessee, Quebec, Virginia, West Virginia and Wisconsin. Although the beetles seem unstoppable in North America, they are little more than a nuisance in Asia, where they destroy only ash trees that are unhealthy or damaged.

Work that began in 2003 in test plots at Michigan State University showed that one species, Manchurian ash (Fraxinus mandshurica), is resistant to ashborer larvae. Research has so far identified four candidate proteins in the soft wood of the species that protect it. The process was accomplished through genetic subtraction, eliminating more than 2000 proteins that Manchurian and North American ash have in common. The proteins as well as phenols that Asian species produce will be tested on borer larvae to see if they are toxic or inhibit growth. Identifying the genes that produce ash borer toxins will be helpful when researchers crossbreed Asian and North American species. A DNA test will be able to show if the resistance is inherited in the hybrid. This genetic tagging could cut years off the process of breeding a resistant tree. Without the tags, researchers would have to wait at least three to four years for a hybrid to grow large enough to be attacked by a borer to determine if it's resistant. Although some nurseries do sell Manchurian ash trees, Herms said,

Some scientists say the key to saving North American ash trees may be locked within the individual Michigan ash trees that managed to survive the initial invasion.

the species does not grow well in North America. He also said Manchurian trees would not be suitable for planting in North American forests because that would introduce an exotic species to forest ecologies.

Project researcher Jennifer Koch, a molecular geneticist with the USDA's Forest Service, said the project will not simply focus on Manchurian ash. Researchers also want to identify the resistance mechanisms and genes in another Chinese species as well as one from Korea. Work also will begin on ash trees that survived the onslaught of ash borers in southeastern Michigan.

Scientists are hopeful that the trees already are resistant to ash borers. They could also be tolerant, meaning that they don't die after repeated borer attacks. "We came up with the term lingering ash," Koch said. "We don't know if they're resistant or tolerant. We know that they are still alive." A resistant tree 
is able to kill its invading larvae. A tolerant tree can survive multiple attacks that produce some adult insects. Trees with the right genes must be allowed to grow to see if they develop all the desirable traits people look for in a North American ash. They also have to see if the resistance genes are automatically passed on in seeds.

Despite a special diet that speeds growth, scientists must wait three to four years for an ash tree to mature enough to reproduce. Another problem is the ash borer larvae. To figure out what kills the insect, scientists must first create a medium that simulates the moist environment and nutrients found in the soft wood of an ash tree, said Don Cipollini, a Wright State University chemical ecologist.

A separate group of USDA researchers is trying to find the right balance of nutrients that ash borers need in their diet. It is the only way to get the larvae to live long enough to start eating the things that might kill them. "You can't let them dry out. ... They can't really crawl very well. They chew their way through their environment face first," Cipollini said. "That makes ash borers challenging compared with other insect pests. Caterpillars are much easier to work with. You don't have all these concerns about humidity."

Source:

Spencer Hunt, The Columbus Dispatch Sunday January $15^{\text {th }}$

\section{New Organizational Structure for FPInnovations}

PInnovations unveiled its new organizational structure in early February to its 550 employees across Canada. The reorganization came about following an in-depth review of FPInnovations' business model, which required a series of changes to better position the organization as a strategic partner to industry members and clients, federal and provincial governments, and the larger research community, especially universities.

FPInnovations will keep a strong hold on R\&D through its collaborative research with forest industry members. To this, it adds a Business Development component which encompasses Strategic Research Alliances, Products and Services, and Licensing and Ventures.

"It became clear that the collaborative research approach, which served us very well for many decades, was no longer sufficient to help us support our members and partners in pursuit of their new goals," noted President and Chief Executive Officer Pierre Lapointe. "Although R\&D remains the heart and soul of the organization, we are now equipped with new business tools to help FPInnovations continue to deliver results in the pursuit of transforming the Canadian forest industry."

Business Development Vice President Hervé Deschênes will ensure the organization's business alignment with potential customers and members in terms of licensing and ventures, building strategic research alliances, and developing new products and services. The business group's reporting structure also includes Intellectual Property and Membership Recruitment, Busi- ness Analysis, and Sales, Products and Services. In addition to leading the Transportation research program, Mr. Deschênes will take on and develop the Markets and Economics group.

Research Vice President of Pulp, Paper and Bioproducts Jean Hamel will lead the following research programs: Market Pulps, Paper, Packaging and Consumer Products, Biorefinery and Bioenergy, and Biomaterials.

Research Vice President of Forest Products and Wood Products Peter Lister will head up the following research programs: Forest Operations, Wildfire Operations, Primary Wood Products Manufacturing, Secondary Wood Products Manufacturing, and Advanced Building Systems.

Research Vice President of Resource Assessment George Bruemmer will lead the Resource Assessment research program, in addition to his other responsibilities with the Canadian Wood Fibre Centre.

The research and business development vice presidents will report to Alan Potter, Executive Vice President, who will ensure that all the research programs and associated research teams present FPInnovations' enhanced value proposition to its industry members, clients and partners. At the corporate level, both Chief Financial Officer Yves Nadon and Strategic Partnerships Vice President Jean-Pierre Martel take on additional responsibilities. Mr. Nadon will be adding Building Services and management of company assets to his responsibilities, which already include the Finance and Information Technologies' departments. Mr. Martel will man- age the organization's relationships with the federal and provincial governments, national and international organizations, as well as university and Aboriginal partnerships.

"I am convinced that this is the right move for FPInnovations. These changes will help us explore new partnerships with energy and chemical industries to name a few," said Pierre Lapointe. "This new structure will be more efficient and offer the most growth potential while ensuring a bright future for FPInnovations' members, clients and partners," concluded Mr. Lapointe.

\section{About FPInnovations}

FPInnovations is a not-for-profit world leader that specializes in the creation of scientific solutions in support of the Canadian forest sector's global competitiveness and responds to the priority needs of its industrial and government members. It is ideally positioned to perform research, innovate and deliver state-of-the-art solutions for every area of the sector's value chain, from forestry operations to consumer and industrial products. FPInnovations' staff numbers more than 550. Its research laboratories are located in Québec City, Montréal, Thunder Bay, Edmonton and Vancouver, and it has technology transfer offices across Canada. For more information see: www.fpinnovations.ca

Source: FPInnovations Press Release February 8, 2012 